\title{
Discussion on the Legal Supervision of Insurance Funds in Capital Market
}

\author{
Ying Liu \\ Department of Business Management \\ Neusoft Institute Guangdong \\ Foshan, China 528225
}

\begin{abstract}
Insurance funds are the important capital in the capital market. Their frequent placards in the stock market in 2016 not only made the management of listed companies nothing to follow, but also were to blame by regulators several times, and insurance funds have become very "dangerous". In this event, are the insurance funds, regulators and investees subject to the rule of law? By analyzing the current situation of insurance funds in the capital market and the legal relation involved in the investment process, this paper tries to put forward the regulatory path to the insurance funds under the view of the rule of law. That is, uphold the idea of rule of law and perfect corporate governance structure; shape the rule of law culture and help to innovate business models; promote ruling city by law and build up credit mechanism.
\end{abstract}

\section{Keywords — the rule of law; insurance funds; capital market}

\section{INTRODUCTION}

The rapid and orderly development of the capital market only builds on the basis of the rule of law that can be a permanent solution. In 2016, the government work report of the central government put forward that "promote the reform of the stock market and rule of law construction and perfect the healthy development of multi-level capital market", which demonstrates the determination of government to establish a law based capital market. To terminate the ST Bo Yuan listing according to the law became an important case of legalization construction of capital market in 2016. In the process of the rule of law in the capital market, the entering and delisting market of capital should be regulated according to law, which can construct a healthy capital market and serve the investors. From 2001 to early March 2016, China Securities Regulatory Commission (CSRC) has issued 785 punishment notices and 174 limited-access market decisions, [1] which is the result of administering the country according to law and administering the market in accordance with the law. However, as the important participants in the capital market, the insurance funds frequently placarded the stock market in 2016 and China Vanke, Gree Electric and other high quality blue chip stocks have been placarded by insurance funds, which became the most eye-catching event in the capital market in 2016 and was interpreted by the outside world as irrational placards. China Securities Regulatory Commission (CSRC) and China Insurance Regulatory Commission (CIRC) officials have repeatedly reprimanded this event, which caused market fluctuations. In this event, insurance funds as an investor,
CSRC as a supervisor and the listed company as a representative of the investee, are the performances of the three parties in line with the idea of rule of law? There is nothing to be said against it that insurance funds enter into the market for value investment, however, if it deviates from the prudent and moderate investment rules, there will be a risk of getting out of line, which will damage the interests of market participants and further occur the illegal consequences, biting off one's own head. If regulators want to punish the illegal activities in the capital market only by delivering signals of heavy punishment through the way of severe reprimand, is it conducive to promoting the rule of law in the capital market?

The construction of the rule of law of capital market requires that all the market participants make concerted efforts and apply the idea and perspective of rule of law to achieve the situation that there are laws to abide by. If insurance funds have obtained the control power of major companies in the event of insurance fund placards in 2016, how should the real economy develop in the future? Will it continue to create wealth as before? Every time when our supervision department encounters the event like insurance fund placards and there are no laws to apply, only by relying on individual authority to lay down the law, how can we achieve the goals from ex post supervision to ex ante supervision and pro-seo regulation?

\section{ANALYSIS OF THE INVOLVED LEGAL RELATION OF INSURANCE FUNDS IN CAPITAL MARKET}

\section{A. Analysis of Legal Relation between Insurance Funds and Regulators}

The madness of insurance funds in the stock market in 2016 attracted the attention of regulators, and the chairman of CSRC and CIRC angrily rebuked the behavior that insurance funds frequently placarded the listed companies. In the legal relation of insurance funds and regulators, the right of insurance funds is to select the investment object to invest and get returns, and the right of regulators within sphere is to supervise the capital contribution behaviors of insurance funds. The behaviors of insurance funds and regulators should be established on the basis of the rule of law, which is the lawful act, on the country, if any party fails to act in accordance with the law and is out of the track of the rule of law, there may be consequences of illegal activities. Based on 
the above analysis, the behavior of frequent placards of insurance funds is suspected of being involved to manipulate the stock price, disturb the market order, damage the middle and little investors' rights and other criminal acts, and the regulators can carry out the supervision and call to account in accordance with the law. If all the cases which can be carried out in accordance with the law can enter into the legal proceedings only after the top leaders give the harsh words and stern looks through the media, is this market a high level of market of rule of law?

\section{B. Analysis of Legal Relation between Insurance Funds and Listed Companies}

As a party of the investment, insurance company invests a lot of funds into the listed companies of stock market, which forms a legal relation with the listed companies of investee. The rights of insurance companies are to choose a company to make investment and get returns, however, the rights of a listed company are to obtain funds according to the investment agreement and its obligation is to allocate profits to the investor according to the agreement. In such a legal relation, if what the investors want to get return is the corporate control right which is beyond the scope of financial returns, the legitimacy of this legal relation will draw on the mark, is the basis of legal relation the true expression of intention of both parties? It differs from the nature of valuation adjustment mechanism of merger and acquisition legal relation. In the valuation adjustment mechanism, one party gives up the corporate control right which is the true and voluntary expression of intention, however, in the relation of insurance funds and listed companies, the investment of insurance companies for the purpose of gaining corporate control right is unacceptable for the listed companies. The behavior of insurance companies only by their unilateral expression of intention seems to bypass the supervision of the law, but it essentially violates the equity and justice of the law. The insurance companies have made big profits and should also bear the social responsibility which matches their earnings. To enter into the stock market, carry out financial investment and play its function of value investment is the legal and reasonable orientation of insurance funds. If the listed companies placarded by the insurance company all have the same fates as CSG Holding A which is taken over by the insurance company, how can the capital market realize the transformation from virtual capital to real economy? The rule of law capital market should abide by the equity and justice value of law.

In the capital market, any party should be within the framework of the law when the transaction is carried out and should establish the legal relation in accordance with the idea of honesty and trustworthiness, fairness and justice, and only by this way can the legal relation be legitimate and valid. The Roots of Wisdom writes that "from the emperor to the common people, all the fearless people have died. Someone fears the emperor in the royal court, the common people in the street, the officer temporarily and the historiographer in later ages". With fear, action can be limited. The wayward action of insurance funds in 2016 doubtlessly resulted in the more strict system supervision.

\section{ThE REgUlatory PATH UNDER THE RULE OF LAW}

Since the reform and open to the outside world, the innovation and development of China's governance system has always been in line with the construction and improvement of the legal system. Market economy is the rule of law economy. The rule of law is the only way for the modernization of the country's governance. The rule of law in the country's governance includes two basic aspects, namely, the legalization of governance system and governance capability. [2] The construction of rule of law in the capital market also needs to apply the idea and way of rule of law to realize the two goals, legalization of capital market governance system and participant governance capability. For the wanton of insurance funds and anger of regulators in 2016 , the author tries to put forward the following regulatory approaches.

\section{A. Uphold the Idea of Rule of Law and Perfect Corporate Governance Structure}

In capital markets, we should apply the rule of law in thinking to invest and manage a company, which is the goal that market participants should do. The management staff of CSG Holding Co.,Ltd that was in placards by the Baonneg Series was in team voluntary turnover, which is called by the media a "decapitation strike" of capital to industry. The incident exposed the two problems, one is the company that has been swept away the corporate control rights by the insurance funds as CSG, because there are loopholes in corporate governance ability that leaving the chance of attack of "barbarians"; Two is there are legal risks in the corporate governance structure of insurance company, which not only deviates from the concept of prudent investment in insurance industry, but also deviates from the rule of law value of fairness and justice. For placards, it should be treated differently. The placards investment income of some small and medium-sized insurance companies can be good for covering their own capital costs. At the same time, its investment object can also form a good synergy with itself, and such behavior should be encouraged. And for some placards through the malicious speculation in secondary market and affecting the normal operation of enterprises should be standardized. In particular, in some aggressive insurance companies, the source of funds faces high liquidity risk. For this short-term financial universal insurance with high current prices, the surrender losses of policyholders are very small. If a large area of surrender occurs, the insurance company will face serious cash flow risk, and it may even affect the stability of the overall financial system. At the same time, the strong externalities of insurance companies may bring about negative social effects; therefore there should be stricter demands on supervision. [3] The realization of the rule of law changes from ex post supervision to ex ante supervision and pro-seo regulation that need the joint efforts of the parties involved in the capital market. The investors and listed companies are the main roles in capital market, and passive acceptance of supervision is far less effective than active self-discipline. Then it is needed that insurance companies and listed companies hold the idea of rule of law in the investment and financing activities and use the rules of law to perfect the corporate governance structure and achieve 
their respective business objectives. Any violation of the value of law of investors, it will occur the joke that CSG management is replaced by insurance funds as the unprofessional and the professional are misplaced.

\section{B. Shape the Rule of Law Culture and Help to Innovate Business Models}

Whether the company's decision is legitimate, it is depended on whether the management has the view and idea of rule of law. The company should carry out institutional innovation to adapt to the rapid development of innovative business models, which needs the accumulation of internal governance culture inside the company. For insurance funds entering into the capital market, in the context of Internet banking with innovative business models emerging, there is no matching system model, which will be detrimental to the company in the development of track of rule of law. Shaping the rule of law culture within the company is a form of learning, law abiding and using culture from top to bottom and becomes part of the company's corporate culture. All departments and their members pursue the culture so as to form the strong atmosphere of the company's rule of law culture, which will help companies reduce costs in the fierce market competition and avoid disputes and remain invincible. The important departments of the company, such as finance department, sales department and purchasing department, any of which that does not act strictly according to law will face legal risks. The core board of directors, shareholders' meeting and board of supervisors of the company's management organization are more concerned with the company's future when making decisions. Chinese and foreign outstanding companies are all the same. Bill Gates founded Microsoft Corp, and its products are world-renowned. In 2015, Apple Corp and Samsung Corp's patent wars often made headlines. As a IT industry tycoon, there are few reports of intellectual property disputes on Microsoft products, which is closely related to Bill Gates's legal literacy and the company's legal culture. Alibaba company itself founded by Ma Yun is an economic model of innovation, and the most valuable thing is, in order to match this new business model, Ma Yun also carried out the innovation of corporate system model. Through the articles of association, the partner's one-vote veto system is embedded in the company's legal system, so as to ensure that after the listing of the company, when the founder shareholder's equity is diluted, $\mathrm{Ma}$, as the founder, still has the right to make decisions about the company's development, which is the value of the rule of law culture.

\section{Promote Ruling City by Law and Build Up Credit Mechanism}

Honesty is the premise of the rule of law, the rule of law is the guarantee of good faith, and good faith and the rule of law environment can support the standardization sustainability and stability of capital market. The rule of law in capital market can give investors steady expectations. [4] It can also help the government regulators work. The principle of honesty and trustworthiness is the basic principle of civil and commercial law, and the process of rule of law in capital market should be based on the establishment of credit mechanism. For regulators, the construction of credit mechanism is a long-term mechanism to rule the city by law. And regulators can change from passive supervision to active supervision according to the credit records of market participants. Such as the event in 2016 that insurance funds are in frequent placards in capital market, regulators repeatedly reprimand the behavior of insurance funds, which is essentially passive regulation and ex post supervision. If the credit mechanism is found, regulators can advance supervision of the behavior that insurance funds are used in unknown investment and set restrictions through legislation, so as to prevent such high-risk funds from entering the capital market to disrupt the normal operation of real economy and impacting of rational judgment of retail investors. The construction of credit mechanism in capital market cannot be completed by legal department independently, and it needs coordinated efforts of information statistics department and network technology department. In recent years, with the rapid development of Internet technology, the Internet financial business has huge increase, and many investment behavior of capital market are also carried out on the network. The sale and purchase of financial products and services in the network are also a part of electronic commerce. It is gratifying to note that the draft of E-Commerce Law has been issued, and the construction of credit mechanism of ecommerce has also been emphasized in the draft. I think that the establishment of credit platform of capital market should be combined with the establishment of e-commerce credit platform, and the credit platform of capital market will be listed as the sub platform of e-commerce credit platform, all of which is convenient for information sharing but also easy to save time and cost of funds.

\section{CONCLUSION}

"Society with rule of law" is the new concept put forward by the third Plenary Session of the 18th CPC Central Committee of the party, and is the new goal and new requirement of building the rule of law in China. In advancing the social construction of the rule of law, the government must correct positioning, neither absence nor dislocation, and do what ought to do and don't do what should not do. [5] To achieve the goal of ruling city by law, the government regulators at all levels shall change the concept and perfect the laws and regulations of ex ante supervision, the risk capital entering the market can "change danger into safety".

\section{REFERENCES}

[1] Zuo Yonggang. The Capital Market Regulation is Forcing the Rule of Law Construction This Year. [EB/OL].(2016-03-31). http://finance.sina.com.cn/roll/2016-03-31/doc-ifxqxenp8253976.shtml

[2] Zhang Wenxian. Ruling by Law is the Only Way for the Country to Govern Modernization. Legal System and Social Development [J].2014.5

[3] Caixin online. Savage and Helpless Insurance Fund Placards [EB/OL].(2016-12-16). http://opinion.caixin.com/2016-1216/101027761.html

[4] Xinhuanet. Promoting the Prosperity of Capital Market by the Rule of Law. [EB/OL].(2014-08-28) http://news.xinhuanet.com/live/201408/28/c_126930330.htm

[5] Li Buyun. The Innovation of Social Governance must be Brought into the Orbit of Rule of Law.People's daily[N].(2014-01-15). 